\title{
Mind the (tax) gap: an ethnography of a number
}

Lotta Björklund Larsen

The self-archived version of this journal article is available at Linköping University Electronic Press:

http:// urn.kb.se/ resolve?urn=urn:nbn:se:liu:diva- 138448

N.B.: When citing this work, cite the original publication.

This is an electronic version of an article published in:

Björklund Larsen, L., (2017), Mind the (tax) gap: an ethnography of a number, Journal of Cultural Economy. https:/ / dx.doi.org/ 10.1080/ 17530350.2017.1323228

Original publication available at:

https:// dx.doi.org/ 10.1080/ 17530350.2017.1323228

Copyright: Taylor \& Francis (Routledge): SSH Titles

http:// www.routledge.com/ 


\section{MIND THE TAX GAP}

\section{An Ethnography of a Number.}

\section{Lotta Björklund Larsen, Tema T, Linköping University}

'Mind the gap' announces the subway driver through the loudspeakers as the doors open. We are therefore careful when getting off, perhaps taking a more deliberate step over the gap while glancing into it. The void is seldom very wide, yet it is dark and murky, and hardly anything can be seen if one looks down. The smell seeping out is far from pleasant - it is a mixture of metallic odour from screeching subway wheels against the rail, abandoned rubbish from careless travellers and debris and filth amassed over years. How far is it down to the tracks, to some solid ground? Is there even solid ground? What is there? Do we want to know?

To think about the gap in a subway station is a way of investigating how tax gap measurement is calculated while focusing on what such a number could or should contain. The tax gap is a versatile number used for various purposes. Estimating the gap is obviously a way of assessing the amount of missing tax income in society; a 'rough indicator[s] of revenue loss' (Fiscalis 2016, p. 11). Following its development over time - is it shrinking or increasing? - is also a way of assessing the efficiency of tax collection (e.g. OECD 2014). Furthermore, to know what constitutes the gap and how it is made makes it possible for tax collectors and policy makers to introduce measures to increase tax compliance. The tax gap is thus an example of figures that perform a dual function: on the one hand mobilizing people's morals and subsequent commitments and on the other hand measuring such commitments (cf. Kornhauser 2007; Ballestero 2014, p. 29). The tax gap number is an aggregate that has very specific political aims for a tax collector but is, as we will see, also used for framing a variety of political agendas. Misunderstandings of causalities and/or outright incorrect narratives of what these gaps consist of can lead to policies that are wholly detrimental for getting to grips with tax compliance (Giles 1997); foster unnecessary division between categories of taxpayers (Hasseldine \& Morris 2013); and create false expectations of revenue (cf. Forstater 2015). It is a potent number.

This article looks carefully at the making of the tax gap as a calculative practice (Miller 2008) by the Swedish Tax Agency (hereafter the Agency), points to the challenges in assessing it (of which the makers of this number are very much aware) and reveals examples of its careless usage by various stakeholders in Swedish society who aim to impact tax compliance discourse. This careful investigation of the tax gap number also illustrates two more general points.

First, the tax gap is yet another example of how a very uncertain number is calculated yet used with certainty in society. It is considered a 'strange, ambiguous and uncomfortable' number (Seabra-Lopez 2015, p. 213) among those who make it, which is also duly noted in the cautious explanations surrounding it. Yet once outside the informed audience of tax analysts and researchers, the tax gap number seems accepted and is somewhat carelessly used for various purposes. I draw in this article attention to the seducing power of a simple number that describes a complicated reality (cf. Porter 1995) - a number that can be used so swiftly to put forward (m)any political arguments. If we rely on the tax gap in order to retain tax compliance, it is of the utmost importance to get this number as correct as possible. 
Second, in this deconstruction of a number, I want to challenge the metaphor of the ubiquitous 'black box'; a very apt concept in many circumstances yet not always the most fitting. We mostly hear about the search for such a box after airplane crashes. It contains the recording of a flight and is therefore relied upon to make us understand why the plane went down; what happened in the interim between the plane's smooth flight in the sky and its scattered remnants on the ground. The black box is also an often-used metaphor for investigating, as for example Donald MacKenzie notes, 'devices, practices, or organizations that are opaque to outsiders because their contents are regarded as "technical"” (2005, p. 555). The tax gap could be seen as such a black box; a carefully aggregated number illustrating a complicated reality made in a very specific calculative space. Although the Swedish assessment of the tax gap is published with detailed explanations of underlying calculations and with many caveats about its relevance along with cautionary advice on its usage (Skatteverket 2008, 2014), these arguments are seldom invoked when this number is referred to in public debate. The Swedish tax gap number is a calculated device (cf. Callon \& Muniesa 2005) and as a specific number can be unpacked as yet another black box. But if we think about what a tax gap ought to contain I argue that we also have to think outside the box and beyond; we have to think about what was not included in the published tax gap number and why there was no room for it. I therefore aim to direct your gaze to the black void of a concept that is, I argue, impossible to assess.

The Agency provides an ideal place for looking into tax gap calculations. In recent surveys citizens have held this bureaucracy to be among the most highly esteemed of all the nation's government agencies (e.g. Arkhede \& Holmberg 2015, p. 22) regardless of respondents' political opinions, gender, class or age (Engelbrecht \& Holmberg 2015, p. 9). The Agency is perceived to be doing its job well, making most, if not all Swedish taxpayers comply, despite the fact that Swedes pay among the highest income tax rates in the world.

I base my argument mainly on an ethnographic study of documents (Riles et al. 2006; Holmes 2009, 2014; Björklund Larsen 2015) following how the tax gap has been made and used by various stakeholders in Swedish society. I explore the tax gap as a cultural phenomenon; by looking at its construction, its usage and the arguments used to support or defy it in various documents. Two kinds of documents have been used; on the one hand the very detailed reports describing the calculation of the number; and on the other hand, newspaper articles that describe the number's various usages throughout society. As we will see, the detailed and descriptive calculations are supported by many caveats. I therefore treat these very different kinds of documents as ethnographic objects as I try to apprehend the argumentative concerns of the authors (cf. Riles 2006, p. 17). In addition to the documents, insights are also based on participant observation within the Agency for three years following a risk assessment project (Björklund Larsen 2017). Reducing the tax gap is even stated as being one of the Agency's two principal aims $^{1}$ (Skatteverket 2014, p. 6) and the number is an omnipresent issue at the Agency. Throughout my fieldwork did references to the tax gap surge in general discussions, in strategy documents and in formal presentations that occurred among groups of employees.

This article starts by situating tax gap calculations made by three OECD members' tax authorities (Denmark, the UK and the US); it proceeds to unpack the Swedish way of assessing

\footnotetext{
1 The other aim is to retain high legitimacy within Swedish society.
} 
tax compliance and then illustrates some instances of how this number has been used in Swedish public discourse. The article ends with a discussion of the need to look outside the black box when it comes to assessing numbers such as the tax gap, and reluctantly notes that a reliable tax gap number is an impossible wish. Added to the fact that the Agency was unwilling to publish an updated tax gap number in 2014, the ten-year-old Swedish number is still, and probably will continue to be, used to represent a very complex reality. And therein lies the danger of the gap.

\section{Making up the tax gap}

Collecting taxes, and avoiding contributing to the very same, goes hand in hand throughout history. Revenue collectors have pursued, chased, enforced and even cajoled taxpayers to pay up using various arguments and strategies. During the last couple of decades, many revenue authorities calculate the tax gaps in order to assess the amount of taxes due while aiming to understand why taxpayers do not comply.

To estimate the national tax gap is a task encouraged by $\mathrm{OECD}^{2}$ and performed by many of its members' tax authorities (OECD 2008, 2010). The tax gap is 'the total amount of tax not collected resulting from all forms of non-compliance in a particular fiscal period' (OECD 2008, p. 11). The gap is an estimate of tax compliance and is supposed to illustrate: to what extent taxpayers pay 'the correct tax'; that the correct amount of revenue is collected; and that the tax administration system has integrity and is efficient. Noteworthy is that OECD notes there is no single phenomenon such as the tax gap; there will always be at least as many tax gaps as there are taxes to monitor and collect (2008, p. 15). This means that various tax collectors define the gap differently and it also implies that even the same collector is continuously challenged by changed and/or new taxes. These might not be easily collected and can thus have negative impact on previous estimates of the tax gap number. Any gap number varies not only due to changed enforcement over the years but to changes in the very content of taxes due as well as how the economy at large performs (e.g. IRS 2016, p. 8).

The American Internal Revenue Service (IRS) has since 1979 periodically estimated a tax gap number. Its definition has changed slightly over the years. In the latest estimate for 2008-10 the definition says: 'The gross tax gap is the amount of true tax liability that is not paid voluntarily and timely' and the net gap 'is the portion of the gross tax gap that will not be paid' (IRS 2016, p. 2). The difference between the net and the gross tax gap amount are taxes paid late and those collected by diverse enforcement activities. The American gap mainly consists of three parts: nonfiling, which is the amount of tax owed but not filed voluntarily and timely; under-reporting, which is income not reported in otherwise filed tax returns; and underpayment, which are taxes reported but not paid voluntarily or timely (IRS 1996, 2016, p. 3).

The methodology to assess the American tax gap has recently changed. The number was for many years based on a large random audit of taxpayers performed back in 1988. This result was extrapolated to encompass the entire population, assuming that non-compliance rates for each tax source were unchanged (Slemrod 2007). The cost for actual audits are high so in addition

\footnotetext{
2 OECD (Organisation for Economic Co-operation and Development) is an intergovernmental economic organization of 35 countries, founded in 1961 to stimulate economic progress and world trade.
} 
there are various other sources for assessing this gap. Supplementing the extrapolated historical audits is information from enforcement strategies as well as from studies on (the lack of) particular types of income such as interest, dividends, tips and informal cash earning activities such as baby-sitting (Slemrod 2007). The last survey (for the years 2008-2010) claims to have improved accuracy based on new and better data (IRS 2016, pp. 11-14).

In the UK, the latest tax gap is referred to as 'the difference between the amount of tax that should, in theory, be collected by the HMRC ${ }^{3}$, against what is actually collected' (HMRC 2016a, p. 5) which makes for a slightly more modest definition than the previous one, which stated that the tax gap was the 'difference between 100 per cent compliance and actual compliance' (OECD 2008, p. 43). HMRC discriminates between diverse taxes in its measurement attempts, yet notes that it has not found a 'reliable measure' that explains the tax fraud part of the gap. HMRC notes that the gap is tax lost for a variety of reasons; from careless tax returns to criminal attacks on the tax system (HMRC 2016a, p. 3) and that the link between the amount of secured revenue and the size of the tax gap is not straightforward (HMRC 2016b, p. 7).

In 2007, the Danish Tax and Customs Administration (SKAT), started a comprehensive compliance measurement exercise for different types of business sector categories (OECD 2008, p. 70). Information was gathered from a broad range of taxpayer compliance data which in turn was based on more than 10,000 tax return audits randomly sampled. These data include the type and magnitude of taxpayer errors and geographical compliance dispersion. Insights and experiences learnt from these audits are used to redesign SKAT's compliance strategies. In the latest calculation, the Danish tax gap is divided into 22 segments, each having its own characteristics, assessment and resulting strategy to reduce the gap (SKAT 2016, p. 5). Examples of these segments include taxpayer employment categories, the black economy, real estate and transfer pricing. Knowledge derives from control activities on identified risky tax areas such as organised fraud and from SKAT's analyses designed to increase knowledge about noncompliance activities.

These few examples illustrate the multifarious definitions and ways of assessing the gap. What the selected tax collectors have in common is noting that the tax gap is capricious, yet somehow relying on its sense of direction over the years. HMRC notes that 'there are many sources of uncertainty and error. However, it gives an indication of our long-term performance - we have seen that the tax gap has decreased since 2005-06' (HMRC 2016a, p. 5). Noteworthy is the IRS' humble and modest tone explaining its' assessment; it stated that 'The tax gap provides a rough gauge of the level of overall non-compliance' and 'estimating the tax gap is inherently challenging and requires assessing the merits of alternative methods, assumptions, and data sources' (IRS 2016, p. 1). Such caveats were absent in earlier measurement reports although the tax gap has always been referred to as an estimate (e.g. IRS 1996).

\section{'Skattefelet' - the Swedish tax gap}

Definitions of the tax gap and methodologies for calculating it differ between countries, and the Swedish measurement suggests yet an additional way. The Agency is one of the tax collecting bodies that have adopted a more philosophical approach (OECD 2008, p. 16) perhaps in line

\footnotetext{
${ }^{3}$ HMRC, Her Majesty's Revenue and Customs.
} 
with the Agency's moral motto 'Our vision is a society where everybody wants to do their fair share' (Vår vision är ett sambälle där alla vill göra rätt för sig) prominently displayed on its website. The Agency's gap is defined as the calculated 'difference between the tax that would have been determined if all those liable for tax reported all their business and their transactions correctly, and the tax that is actually determined after the efforts of the National [Swedish] Tax Agency to ensure compliance' (Skatteverket 2008, p. 5).

In the best of worlds, the tax gap is nil; the revenue authority's estimate of collectible taxes and taxpayers reporting of the same would then be equal. In contrast to many other countries, the Swedish tax gap has nothing to do with the actual amounts collected - as for example the IRS definition suggests - but is a purely calculated construct where no consideration is made for actual fiscal income. However, in an even better world these two numbers would equal the amount the Agency actually collects. Such a state of affairs implies that taxpayers and tax collectors would share an understanding of how tax laws are interpreted; how the tax system works (cf. Skatteverket 2008, p. 9). To narrow the tax gap, the Agency argues that taxpayers should be led to understand how the tax law is applied (Skatteverket 2008, p. 16).

The 'difference' in the tax gap definition suggests a subtraction of sorts, yet the Swedish tax gap is an estimate of the space between taxpayers 'correct' reporting and how the Agency determines tax income. The Swedish tax gap has been estimated since the 1990s and is made up of 'all available information of tax fraud and other errors by taxpayers' (OECD 2008, p. 68). It reflects what the Agency currently knows about the missing tax income (ibid., p. 69). The calculation can be regarded as a pedagogic exercise that aims to show the magnitude, identify areas where more knowledge is required and facilitate both external and internal communication of noncompliance. Voluntary compliance theory suggests that taxpayers' willingness to pay up depends on the perception that all other taxpayers pay their share. A small tax gap is one of the measures that aim to show how efficient tax collecting authorities have been in their collecting endeavours in light of changing strategies. In order to mirror increased tax compliance in society, the gap is a measurement that ought to diminish over time. New knowledge about tax errors may however change the estimates $(2008$, p. 21) so that paradoxically an increased tax gap may reflect increased compliance among taxpayers, rather than a more knowledgeable and insightful Agency. Still, in 2008 it was the Agency's explicit goal to halve the tax gap by 2012 (ibid., p. 9).

Estimating the tax gap is a recurring task for the Agency. Learning about the tax gap, as the OECD proposes, only suggest changing strategies; but if the gap is shrinking, it also legitimizes such changed strategies. Although this gap is recognized to be 'surrounded by a great deal of uncertainty' (OECD 2008, p. 68) a decreasing tax gap number is, supposedly, the sign of a successful of tax collector. So for 2007 the [Swedish Tax] Agency published a tax gap result of 133 billion krona, which in relative terms is stated to be about $5 \%$ of GDP or $10 \%$ of the determined tax to be collected.

The 133 billion is roughly made up of three different types of tax errors.

First, about $50 \%$ of the total number derives from undeclared work. 'The definition is broad and encompasses both undeclared wage payments and undeclared sales in companies as well as unreported withdrawals and private expenses deducted in the company' (Skatteverket 2008, p. 5). 
About a third of the tax gap number is international. 'International' consists of foreign individuals with income in Sweden, Swedes with income from abroad or other forms of transaction between Swedish taxpayers having activities in other countries. Obviously, the international incomes in question are those that ought to have been subject to tax assessment in Sweden but have not been for various reasons.

Finally, one sixth of the gap is made up by other national transactions. These do not fit any of the above groupings, and might be the result of incorrect deductions, errant calculations of capital gains, using the wrong VAT rates etc.

This is one way to slice the tax gap numbers. This is mainly based on different risk assessment projects ${ }^{4}$ performed by the Agency. There are two other ways to slice the tax gap number.

Second, the Agency also notes that the tax gap can be allocated between different groups of taxpayers: private individuals, micro-companies, small and medium-sized enterprises (SMEs), large companies and finally the public sector including non-governmental organizations (NGOs), foundations and non-profit organizations. The brunt of undeclared work is for example said to occur in micro-companies, amounting to 52 billion krona or about $40 \%$ of the total gap.

A third slicing of the tax gap number is by type of tax: income tax, tax on capital, social security, VAT, excise duty and other.

Regardless of whether we look at the origin of tax errors, categories of taxpayer or the variety of tax types, we need to focus on actual calculation practices. How did different analysis methods create data to add up the 133 billion? The tax gap number originates from a variety of knowledge sources but mainly from statistical data.

Statistics is both a method and a set of knowledges that is frequently used and referred to by analysts at the Agency. For some at the Agency, statistical data is even the very core of knowing (Björklund Larsen 2017). If an analysis poses questions whose answers are not quantifiable or can be related to other quantifiable data, it is seldom knowledge worth knowing. Many employees at the Agency would adhere to the claim that 'modern statistics is the strongest language of all' (Asad 1994, p. 78) in the sense that producing numbers according to approved statistical methods is convincing and reliable. Statistics, and the comparisons those numbers render possible, are needed if we are, in time and space, to reconstruct 'moral and material conditions for target populations' (ibid.). This does not only ring true at the Agency, but also in the way the numbers are more widely used (to which I will return).

But criticizing the tax gap is not a simple task of pointing the finger at statistics. As we know, statistics applies various methods and plays a role in many other academic disciplines, notably economics, political science and sociology. We rather need to direct the gaze towards whatever types of practice are included in the statistical calculations as well as how and if they can be quantified by the Agency.

\footnotetext{
4 The Agency performs annually a number of these risk assessment projects in order to address issues that put it at risk of failing in its duties and to collect the taxes as ordered by the Swedish Parliament (and more explicitly instructed by the Ministry of Finance).
} 
Importantly, the tax gap number is not a snapshot at a given point in time, but a result of different analysis projects and audit control work that have taken place at the Agency during the 15-20 years prior to the publication of the 133 billion. This information has been collated, structured and analysed in what is called a tax gap map. Its purpose is to create a general and informative presentation of what makes up the tax gap and is a general resource for constructing tax gaps (cf. IRS 2016). Based on the map, the Agency estimates a number. The Agency writes:

An analysis of the tax gap and its components gives us a better view of what we know today and what areas we need to know more about. An analysis of the tax gap and its components also gives a better ability to judge what we need to know in order to follow the trend in the tax gap over time. (Skatteverket 2008, p. 10)

Depending on how you read the tax gap map, you can thus learn about which type of transaction affects tax collection, who avoids paying taxes and which governmental income - tax - is most affected.

Noteworthy is that the Swedish tax gap is not only seen as based on intentional errors - those that are made to reduce taxes paid. 'Complicated tax rules or ignorance of the rules that apply may lead to errors in a tax return that are made by mistake' (Skatteverket 2008, p. 16).

A big chunk of the tax gap map derives from a large project on undeclared work ${ }^{5}$ (Skatteverket $2006,2007)$. The purpose of this project was to apply a number of different methods in order to 'solve the puzzle of undeclared work in Swedish society', as one of its authors said in an interview. The framing of this project was a macro-analysis with external data taken from the national or financial accounts at Sweden Statistics (SCB). These data are independent of the taxation process $(2008$, p. 21), but are used to calculate how much tax ought to have been paid. One part that makes up the macro-estimate is the simple subtraction of all Swedish households' reported income, from the same households' expenses and savings. The result reflects the households' 'missing income' (from the Agency's perspective). It can thus be assumed that this income originates from payments 'under the counter' and from faulty bookkeeping. It thus encompasses most taxpayers: entrepreneurs and self-employed as well as employees. It is however a true macro-estimate; as the distribution of such incomes is unknown, it cannot say much about the amount of tax missing among the different categories of taxpayers or why the tax is missing.

Additional analyses are then made to supply micro-level information on the extent of participation for each taxpayer category. For example, the Agency compared historical audits of income for self-employed with income for employees during a ten-year period (1995-2003). The results from these audits were then extrapolated for the entire Swedish business population - for example according to type of company, size of company and sector - followed by a number of adjustments removing extreme residuals. The resulting figure substantiated about $60 \%$ of the macro-estimate.

\footnotetext{
5 The Agency defined 'black work' as '[p]ayment for work carried out, that should be subjected to tax in Sweden but has not been declared to the Swedish Tax Agency' (Skatteverket 2006B:19).
} 
A second comparison ${ }^{6}$ was made between income and food-expenses ${ }^{7}$ for employees and the self-employed. The argument for such comparison is that the self-employed should spend as much money on eating as do employees and any difference in income to the formers' disadvantage is attributed to revenue from the 'black economy' (cf. Engström \& Holmlund 2006). A third explanation is derived from interview studies on households' consumption of and involvement in undeclared work (Skatteverket 2006). The results from these three analysis methods contributed to about $85 \%$ of the overall macro-estimate. In order to transform this number into a missing tax assessment amount, analysts used the median tax rates that reflect the population at large. It was pointed out that there were no concerns of whether the missing income related to low- or high-income earners. Similar inventive and thoughtful wriggling with micro- and macro-data made up the 'international' and 'other national' parts, just as well as if the gap number was sliced according to the range of taxes.

There is however an astute awareness of the shortcomings of the tax gap number at the Agency where some assessments and statistics are deemed more reliable than others. The random audit control, e.g. randomly selected taxpayers that are audited for certain types of income or deductions provide the most reliable data. Such an audit compares reported tax returns with the actual income, bookkeeping entries and supporting documentation, sometimes verified by visits to a taxpayer's office or home. There are however only a few areas of taxation covered by such audits. At the other end of the tax gap certainty spectrum are numbers derived from international connections. These data mainly derive from MNEs tax activities where it is difficult to say what is right or wrong; there is a not insignificant amount of tax avoidance if not evasion (cf. Hasseldine \& Morris 2013). The Agency concludes the report by stating that 'In view of the great uncertainty in the calculations the tax gap map should be used with caution' (Skatteverket 2008, p. 6).

The Agency is thus very careful on the wording when publishing this number (or any number that addresses unpaid taxes). The tax gap is based on what the Agency knows about contemporary tax errors and this might change with new knowledge (Skatteverket 2008, p. 21). And as the exact amount of the tax gap is unknown, the Agency definitely does not know the reasons why the correct tax is not paid. The Agency wisely stays away from stating why the numbers are created; although they derive from several types of tax faults and errors, the Agency says that it can never know if these are made up of unintentional errors or of cheats (intentional faults). Although the Agency does not state the gap as a guesstimate, it has some of its characteristics. I do not mean guesstimate in the pejorative sense as it is definitely not the product of sloppy work or pure guesses; but due to its very nature it is an estimate made with incomplete information.

\section{A number let loose: various usages of the tax gap number}

\footnotetext{
${ }^{6}$ This work is based on the assumption that self-employed under-report income to a larger extent than do employed taxpayers.

7 There exist very detailed data on Swedish household grocery consumption in the public statistics.
} 
Amongst tax-interested individuals in Swedish society, the tax gap of 133 billion krona is well known. I suggest that this is for a number of reasons. First it depends on its capacity to act, the very fact of its being a persuasive number (Porter 1995). The agency of such a number depends on the fact that it is always presented in context (Crump 1978; Porter 1995; Callon \& Muniesa 2005). It is produced by one of the strongholds of Swedish bureaucracy and is based on a number of research methods. Second, when it is compared to something it becomes relevant. As a percentage, it communicates not only its own story but also its relationship to other numbers (Ballestero 2014). For example, a hint of what it entails is when the Agency relates the tax gap number to other public numbers such as GDP or total tax collected (5\% resp. 10\%). This brings us to the third point. The Agency explains the shortcomings of the numbers in great detail, yet all the elaborated caveats expressed in obtaining these seem muddied by the simplicity of the digits - the 133 billion. Despite many caveats consisting of detailed explanations of how the gap number is assessed, the gap takes many routes. It is not the originators of the tax gap number that make the story about the Swedish shortfall, but the people that use it (cf. Holmes 2009, 2014).

Douglas Holmes argues with his concept of 'the economy of words' that central bankers steer the path of how the economy will perform by carefully narrated stories $(2009,2014)$. He shows how central bankers have since the 1980s nurtured a communicative relationship with the public. By persuasive stories - not by exchange rates and outcome of models - the public has been convinced of how the economy will perform which in turn has had an impact on their economic behaviour. The central bankers thus influence the economy, not from the outcome of econometric models (cf. Callon 1998), but by words. Financial markets are thus a function of language substantiated by selected models and numbers (Holmes 2014, p. 89). Holmes's point is that the inputs and assumptions going into models are subject to careful reflection and judgement (ibid., p. 94). Numbers are there, but it is the intended policies that govern which one of the many model calculations will be used to substantiate the argument.

Yet, contrary to Holmes's depiction of words making economies, the Agency loses control of the tax gap number. Its' agency is not found in the original story of how the number is made up and of what, but in what it is referred and related to when let loose from its origin. In the following we will see how this adaptive number is used in various contexts: for comparisons in political debates with heavy moral undertones; singling out certain categories of taxpayers as cheaters; as input to other economic models; when bragging about the efficient Swedish tax system; imagining what might have been, had the gap been nil; and as a quality assessment on how well the Agency fulfils its objectives (Skatteverket 2014).

In the autumn of 2007, basically all Swedish newspapers quoted the Agency's press release. The heading was '133 billion in tax gone' (SvD 17.10.2007, authors translation) in one of Sweden's leading newspapers. The article started by quoting an explanation from the Agency's Director General that not all of it was due to cheating but that a large part was due to ignorance. He also compared the Swedish tax gap result with one from other countries. The argument went that we Swedes are not so bad after all, on par with other Nordic countries with a gap amounting to $5 \%$ of GDP, but better than many other OECD countries. Yet, 133 billion krona is a very large sum. The article compared the number with alternative governmental spending: the judicial system, the defence budget and the universities respectively. It concluded by arguing that if just half of 
the tax gap could be collected, the tax burden could be lowered, with 1000 krona monthly for all employees and senior citizens.

Two years later a similar heading occurred, this time stating '133 billion in tax revenue is missing' (SvD 2009.03.05, author's translation). Both articles are noteworthy in several aspects. First the headings are incorrect. We know that the Swedish tax gap has nothing to do with actual tax payments so there is nothing 'missing' or 'gone'. Second, the latter article occurred two years after the publication of this number. Once again the amount was hammered home; but the underlying message was that now - according to the Director General - the Agency had made considerable improvements in the exchange of international information. The content of the article was thus an implicit warning to all Swedish taxpayers with capital and/or income hidden abroad $^{8}$.

Four years on Dagens Arbete (DA), a newspaper with a smaller circulation and representing a few traditional worker unions, conducted an interview with the second in command at the Swedish Ministry of Finance. The heading was informative: 'It is important to decrease the tax gap, but too difficult to calculate the tax errors' (DA 2011.01.11, author's translation). The article criticized the then right-wing government, arguing that it changed tax rules benefiting entrepreneurs (high-income earners) while not giving the Agency more allowance in the budget to pursue cheaters (high-income earners). Instead resources were provided for assistance in revealing fraud with social subsidies of 193 billion krona (mainly paid to low-income earners). In the article, the fraudulent amount was contrasted with the now very familiar number of 133 billion krona of 'lost governmental income'. The government was thus accused of disregarding the supposedly missing income from high-income earners, while pursuing too generous payouts to needy low-income earners.

A similar number was found to support an appeal for increased sickness benefits. The number 133 billion krona (appraised in 2007) was compared with what the government had argued were the runaway costs of sickness benefits, 132 billion krona estimated at the start of 2000 (Dagens Arena 2010.11.01). The unpaid taxes of 133 billion krona was thus a threat to government finances; if these taxes were collected many more people in dire need of sickness benefits could be helped. Although the numbers originate from different times, the article compares unpaid dues with other much needed payouts. It was another political argument with moral undertones.

An entire political argument unfolds based on numbers that are similar. First, we can see how the tax gap number is used for national comparisons. At a closer look this seems like comparing apples and pears. International comparisons of the tax gap are meaningless, as definitions and calculations differ between countries. Domestically missing governmental income (supposedly from high-income earners) is contrasted with chasing wrongly paid out or inadequate welfare benefits (supposedly to low-income earners). Second, choosing similar figures of expenditure facilitate very moral arguments; the high-income earnings of 'cheats' are compared with expenditure on the sick and disadvantaged citizens in dire need of benefits.

\footnotetext{
8 This apparently has paid off. There has been a noteworthy increase in reported capital income during the last three years.
} 
Third, the Agency's promise to work towards reducing the tax gap number by half was taken seriously by (at least) one politician in the Swedish Parliament. Jacob Johnson (V) ${ }^{9}$ asked the finance minister (2011.05.11) what actual measures had been taken following the publication of the tax gap map a few years earlier. Johnson recognized the calculative uncertainty, yet acknowledged the insights from the Agency that the tax gap was abating, but not being halved by 2011 as originally promised in 2007. What had the Agency done to reduce it? So here the efficiency of those making the tax gap number is highlighted.

Fourth is parts of the tax gap used to connect with the behaviour of certain taxpayer categories. Who is to blame for causing the tax gap? Dagens Industri, the Swedish version of a pink business newspaper, choose to comment on the tax gap, noting that micro-enterprises were singled out as the main 'contributors', with 52 billion (DI 16.10.2007). The Agency's Director General explained why these small businesses bore the brunt of the gap:

To run a small company is quite complicated, especially when you have to take care of and account for everything yourself. We [at the Agency] can contribute by writing explanations and keeping the web updated and available, but we cannot do anything about the actual laws and regulations. A big problem is that these are being accommodating to large corporations'.

This defence of smaller corporations has to be seen in the hinterland of Swedish tax discourse. Micro-enterprises regard themselves as named and shamed in society when it comes to tax faults. In a regional newspaper, Per Lidström, Chairman of the Association of Small Corporations (Företagarförbundet), raised several objections following his association's investigation of microcorporations' contribution to the tax gap (Kristianstadsbladet 2008.09.18). He demurred on several issues. First, looking more closely at the numbers reveals a more equal distribution of problematic behaviour among taxpayers. Second, audits (argued to provide the most secured result in tax gap numbers) are most easily performed on small corporations. And if compliance errors are found, these types of taxpayer are more likely to be identified as a larger risk in the next random audit control. This continues a never-ending (for micro corporations) vicious circle that reinforces the view that these types of taxpayer are less prone to pay their share. Third, everybody getting an income 'on the side', e.g. participating in the black economy, are classified as small entrepreneurs regardless of their legal status, thus becoming part and parcel of microcorporations. Lidström concluded that the Agency continues to regard micro-corporations as potential cheaters, whereas an employee is seen as more honest. It is about time to weed out doubtful calculations and historical categorizations of who errs over taxes, he stated.

Countering the implicit accusation of micro-corporations bearing the brunt of the tax gap (about a third), this argument challenges the calculations allocated to the category of taxpayers Lidström represents. The article did not contain any reference to 133 billion krona or any other amount, percentage or part of missing governmental income. Instead, Lidström challenged the Agency's categories of taxpayers based on individuals' tax paying behaviour. He implicitly accused the Agency of being lazy and not challenging old perceptions of who pays and who does not. Perhaps all taxpayers are cheaters/wrongdoers? If they are, the Agency continues to pick the low

${ }^{9} \mathrm{~V}$ stands for the Left Party. 
hanging fruit of easily audited companies (i.e. the smallest ones) and thus reinforces 'the knowledge' of who errs. In addition he wrote that the Agency creates incorrect classifications as it defines all cheaters as entrepreneurs.

Perhaps Lidström can agree with the Director General that the tax laws are not written for smaller companies. However, Lidström can also be seen to argue that the Agency has a strategy of 'economy of words' (Holmes 2014) where published data and results are based on the narrative it wants to communicate. This is an unwelcome story for the Agency despite the careful caveats about the calculations. The Agency does not want to single out small businesses.

In another more direct attack on the tax gap number, former Left Party Leader Lars Ohly, in his summer speech of 2008, talked straightforwardly about the tax gap as cheating, (skattefusk). His argument was that the government misses out on more than 130 billion krona each year due to tax cheating which means less money for social welfare. The government lacks the initiatives to fix the cheating, which also means coming to terms with the social dumping frequently found in the black economy. An old argument of who is seen to err is again challenged, with erring parties compared to cheats, regardless of whether defending or accusing the singled-out category. It is conveniently forgotten that the Agency indicates that it does not know the intention at the time that tax errors are made.

It is worth repeating that the Swedish tax gap has 'great uncertainty', is philosophical and theoretical and has nothing to do with the actual income collected - yet it is used for a number of comparisons. As Andrea Ballestero notes

do numbers draw their political and popularized power from widespread desires for openness, transparency, and visibility, even at the expense of nuanced and more precise accounts of the world... Paradoxically, though, it is also well known that numbers do not have intrinsic truth-telling capacities but, as any other semiotic resource, can be used to produce all sorts of stories. (2014, p. 39)

\section{Criticism of the tax gap number}

Although the number has succeeded in being widely quoted ${ }^{10}$, it is of course a subject for critical voices. The IRS tax gap has been criticized for under-reporting income from informal suppliers, tips and other such income that is not subject to third-party information (e.g. Alm \& Erard 2005). Norman Gemmell and John Hasseldine (2012) provide a critical overview of tax gap measurements with empirical focus on the IRS noting that 'there are few, if any, reliable methods of measuring tax gaps as conventionally defined'. Even if we take the number seriously, none of these measurements pays any regard to how changes in enforcement to close tax gaps incorporate behavioural responses; it is just assumed that taxpayers comply with the missing gap number (ibid.).

Even the OECD's initial encouragement (through its Forum on Tax Administration) changed while gathering the recommendations. From the initial 'measuring' it went to the final title Monitoring Taxpayers' Compliance: A Practical Guide Based on Revenue Body Experience (OECD 2008, p.

10 To google skattefelet (the tax error) gives 4500 responses, skattefusket (the tax cheatjng) 12000 response and 133 miljarder + skatt gives 83800 hits (as of 15 June, 2015). 
24). Later OECD reports on tax compliance even suggest that the very release of a number might have negative effects on compliance (OECD 2014, p. 27). In the latter report it is noted that 'these methods are inevitably backward looking and of limited usefulness for operational management' (OECD 2014, p. 20). The focus has moved to suggest 'practical outcomeorientated performance measures' (ibid.) that are forward looking. Was the tax gap perhaps somewhat of a passing fad in applied tax compliance research?

The Agency itself was also affected. Despite being very careful to point out flaws in the gap calculation and pedagogically emphasizing what the number could be used for in the original publication, it has been criticized for using it to overstate its own success. The Swedish National Audit Office (NAO), Riksrevisionen, points out that in its 2012 Annual Report the Agency stated that the tax gap contents, and therefore also the tax gap, developed in a positive way between 2011 and 2012, but without showing how the underlying data are statistically secured. The NAO recommends that the Agency does not go beyond what the underlying calculations and studies in future assessments of the tax gap can say (Riksrevisionen 2013).

Despite the caveats and changed agenda on tax compliance measures but possibly also due to the NAO's critique, the Swedish government six years on (in the 2013 Appropriation Directives) ${ }^{11}$ ordered the Agency to: renew the tax gap map; quantify the tax gap; and describe changes in the gap between 2007 and 2012 (Regeringen 2013). The Agency put much work into the project, yet actually declined to quantify a new tax gap number stating that it was impossible given the changed quality of data (Skatteverket 2014). The main reason stated was a change in audit practices. These were now less general but more detailed as they were being directed towards taxpayers with a high-risk profile. The audits could therefore not be used as a sample for the entire population. In addition, audits are expensive and have been reduced in number since the last gap was assessed. The Agency also underlines the international trend of hesitant reliance on tax gaps writing that ' $[\mathrm{m}]$ apping and estimating the tax gap is complicated and not an exact science, since part of the tax gap is concealed and undetectable. This is an experience we share internationally with several other tax administrations.' (Skatteverket 2014, p.5). The only assessment that the Agency could pronounce 'with a high degree of uncertainty' (ibid.), was that the tax gap has probably decreased since last time (ibid., p. 6).

It is a conclusion that demands some explanations and I therefore return to the calculations. First, there is no new tax gap map; instead of mapping missing tax payments a 'tax information map' is provided. The new focus is on knowledge that the Agency has; on the one hand about establishment and control over taxes and on the other hand over the information taxpayers provide for assessment.

Second, it is repeated and underscored that any calculation of a tax gap requires a combination of methods. The top-down macroeconomic calculations (described above) from the National Accounts show no obvious decrease in their estimate (Skatteverket 2014, p. 38), whereas the bottom-up assessments using micro-data or resulting from specific areas of investigation such as attitudinal surveys of the Swedish public on tax evasion have shown a decreased acceptance for such behaviour. Third, legally and regulation wise there have been a number of changes made

11 Appropriation directives, regleringsbrev. An annual letter of instructions that governs all Swedish governmental authorities. 
possible by technological advancements that are known to impact compliance in a positive way: there has for example been tightened control of cash payments; there is more tax filing information coming from third sources [than directly from the taxpayer]; and Sweden has extended its information exchange with other nations, notably some nations that are considered as tax havens (Skatteverket 2014, p. 73).

So instead of a new tax gap number based mainly on audits and extrapolated for the entire Swedish taxpaying population, a very precarious direction is proposed. It would have been hard for the Agency to say otherwise about the gap number. Such messages are a 'communicative imperative' (cf. Holmes 2014, p. 19) as the Agency cannot contradict its standing as a reliable collector in a society where taxpayers ought increasingly to provide their fair share.

Yet, the number of 133 billion krona reappears here and there and seems to lead a life of its own. In a recent interview ${ }^{12}$ I had with a tax expert at the Confederation of Swedish Enterprises about compliance initiatives taken by the Agency, this person questioned the 133 billion krona in 'tax cheating'. Any caveats originally stated in the Agency report (cf. Skatteverket 2008) or that it was almost ten years since this number was published were omitted. So the gap number continues to perform in new contexts and in various ways. Using numbers for these types of political arguments is a mundane practice and happens daily; more interesting for my argument is what is seen as calculable or not.

\section{The black hole of a number}

Obviously there is tax cheating; lots of it. There are also many accidental errors in bookkeeping, when compiling tax returns and when paying amounts due. The problem is to understand what ought to be part of the tax gap and how to quantify it. The Agency recognized that the tax gap map has blank spaces. 'There are areas where we suspect that there may be a really large tax gap, but where we have no material at all with which to verify this' (Skatteverket 2008, p. 21). As Bruno Latour famously noted, black boxing is

the way scientific and technical work is made invisible by its own success. When a machine runs efficiently, when a matter of fact is settled, one need focus only on its inputs and outputs and not on its internal complexity. Thus, paradoxically, the more science and technology succeed, the more opaque and obscure they become. (Latour 1999, p. 304)

James Henry, former Chief Economist at the consultant company McKinsey and now advisor to the Tax Justice Network, used a very 'sophisticated method' to estimate the money kept at socalled tax paradises. Still he states that these methods are all 'exercises in night vision' or the 'economic equivalent of an astrophysical black hole' (Henry 2012, p. 3). Thinking with the notion of a black hole as Henry suggests, I argue that we have to extend our investigation outside the black box to better understand tax gaps 'in the wild' so to speak; what ought to be subject to tax and what is not for various reasons.

I have opened the box of 133 billion krona in the tax gap and unpacked it. But it does not help much as more or less all revenue collectors that estimate the tax gap now deferentially note the unreliability of the figure itself. So numbers aside; if we, like the Agency, take the notion of tax

12 Interview conducted April 2015. 
gap seriously we have to look beyond the idea of the black box. With the Agency's recognition of unknown spaces, the gap seems all of a sudden borderless, or perhaps bottomless. It cannot be contained in a box. We can only imagine what is there by collating what we have read about unreported yet taxable activities during the years: e.g. the array of activities revealed by the socalled Panama papers in 2016; the trivial bartering between neighbours using their skills (Björklund Larsen 2013); or the despicable abuse of paperless immigrants in the truly hidden economy (Khosravi 2010).

\section{Conclusion}

An ethnographic investigation of a well-known number such as the tax gap and its various societal usages raises many questions about our belief in numbers. Although it is published and presented with many caveats and cautions attached to it, we have seen how it is used in very versatile ways when let loose in society. Perhaps its success is due to its great uncertainty and its obscurity? It permits different actors to make use of it (almost) every which way they wish, reinforcing perceptions about who pays taxes, who avoids them, and what consequences such avoidances have.

Politicians wish for easy explanations of complex issues in order to convey simple corrective practices to the public. Numbers are a great tool in their seeming objectivity, especially when provided by one of the Swedish state's most esteemed bureaucracies. Although the reluctant tax experts at the Agency try to explain what makes up the tax gap, this is a number politicians and public decision makers want in order to evaluate tax compliance and bureaucratic efficiency. 'Ideally, expertise should be mechanized and objectified. It should be grounded in specific techniques sanctioned by a body of specialists. Then mere judgement, with all its gaps and idiosyncrasies, seems almost to disappear' (Porter 1995, p. 7).

Yet the tax gap says very little. It is a number that is clearly recognized as a guesstimate by its calculators; numerous caveats in its making are noted in many explicit statements and footnotes arguing for caution while using it. Although they know that the gap exists, calculators underscore the lack of 'basic data' and note that some of the underlying assessment studies do not properly describe sampling methods, population and calculations (Skatteverket 2008, p. 11). The Swedish variety also belongs to the family of tax gaps that has been criticized by tax scholars (Gemmell \& Hasseldine 2012).

I have argued that as a concept a tax gap number is by its very definition difficult to unpack, as a black box cannot even provide room for it. We started looking inside the black box of 133 billion krona; unpacking it revealed large holes and breaches about what the tax gap actually is. Do we really want to see what is down there, in the gap? The dirty and abusive practices in the shadow - black, hidden economy or whatever we choose to analytically call the space where what is considered to contain the tax gap exists.

The tax gap's usage is widespread and this is perhaps the problem with it. There is the repeated illustration of new compliance measures (watch out potential cheaters!); it can compare Swedes to citizens of other nations (we are not soooo bad after all) or put forward a moral reasoning justifying other welfare expenditures (see what could have been had if all paid up). The Agency's lesser ambition to grapple with the number's reduction could be used as a critique of the 
incumbent government asking for simple answers. While shrinking, it is also a measure of the Agency's efficiency. Mostly, the number has erroneously been used to point a finger at some taxpayers' whose compliance is worse than others and call it cheating. Looking at the calculative practices in detail and comparing these with the carelessness that using the number reveals, there are many (imagined) relations between the role taxation plays in economic life and ideas about it (cf. Miller 2008, p. 59); between who is seen to pay taxes and who is seen to avoid them; what can be quantified and what cannot; and between what is seen as subject to tax and practices that are too problematic to even start to recognize them as being part of the taxable economy.

There are various methods and strategies employed to the increasingly complex measurements: from tax collectors' former focus on simple audit yields like the IRS carried out in the 1960s (e.g. the percentage of how much income audits of suspiciously incorrect tax filings yielded compared to the total tax collection); through the usage of a wider array of compliance tools and strategies; and to the current digitalized sampling of risky taxpayers. New tax laws or court decisions continue to prompt adaptations to Agency work praxis with amended controls and audit procedures.

Historically, tax collectors' main strategy to force taxpayers to line up was the threat of audits; today there are many additional tools. New technologies and computer programs enable a more stratified sampling for a variety of different controls; communication and information initiatives aim to simplify citizens' (tax) lives; new research, polls and surveys provide estimates about various taxation practices. All are issues that seem to strengthen compliance.

Simultaneously news in the media creates more headlines on who pays, and who avoids doing so, and thus alters public discourse and our understanding of who complies - and who does not. While many tools are available to illuminate tax compliance, it is still a messy reality. Looking at the calculative practices that make up an illustrative number thus reveals much about contemporary knowledge of tax compliance and current strategies to ameliorate it.

We have noticed a more conciliatory approach from revenue collectors about what they attempt to measure. Policy makers and external auditors demand number(s) and there seems to be an increasingly widespread reluctance to provide them. The European Commission's Tax Gap Project Group noted in a report focusing exclusively on VAT that the ' $[\mathrm{t}]$ ax gap estimations are rough indicators of revenue loss' (2016, p. 11). This hesitation is most notable in the Agency's unwillingness to reveal a specific tax gap number when last ordered to do so. The Agency suggested that the gap, as a percentage of GDP, decreased, but instead wanted to convey verbal facts and knowledge about what makes people comply. This means taking control of the number and instead, borrowing from Douglas Holmes, creating a 'tax compliance of words' (Holmes 2009, 2014). ${ }^{13}$

It is perhaps time to seriously consider scrapping the gap number and concentrating on what the gap contains, as any verbal reasoning about a specific number gets lost in the very complexity of what it actually attempts to measure.

13 Which notably will in turn have implications for the economy. 


\section{Acknowledgement}

An early version of this paper was presented at EGOS 2015 in the sub-theme "Devising Markets and Other Valuation Sites". Thanks are due to participants at this panel and to colleagues at the ValueS seminar at Tema T, Linköping University. I am in particular grateful to discussions with Francis Lee but thanks are also due to Johan Nilsson, Catelijne Coopmans and to the reviewers of this article for most rewarding comments. All the remaining errors are mine.

\section{Funding}

This work was supported by European Union's Horizon 2020 research and innovation programme 2014-2018, grant agreement No. FairTax 649439.

References

ALM J. \& ERARD, B. (2005) 'Estimating the Informal Supplier Tax Gap', Internal Revenue Service Research Conference.

ARKHEDE, S. \& HOLMBERG, B. (2015) Svenska folkets bedömning av offentliga myndigheters verksamhet.

ASAD, T. (1994) Ethnographic Representation, Statistics and Modern Power. Social Research, vol. 61, no. 1, pp. 55-89.

BALLESTERO, A. (2014) What Is in a Percentage?: Calculation as the Poetic Translation of Human Rights, Indiana Journal of Global Legal Studies, vol. 21, no. 1, pp. 27-53.

BJÖRKLUND LARSEN, L. (2017) Shaping Taxpayers. Values in Action at the Swedish Tax Agency, Berghahn Books, Oxford.

BJÖRKLUND LARSEN, L. (2015) 'Common Sense' at the Swedish Tax Agency. Transactional Boundaries Separating Taxable and Tax-Free Income', Critical Perspectives on Accounting, vol. 31, September, pp. 75-89.

BJÖRKLUND LARSEN, L. (2013) 'Buy or Barter? Illegal yet Licit Purchases of Work in Contemporary Sweden’, Focaal. Journal of Global and Historical Anthropology, vol. 66, pp. 7588.

CALLON, M. (1998) 'Introduction: The Embeddedness of Economic Markets in Economics' in The Laws of the Markets, ed M. Callon, Blackwell, Oxford, pp. 1-57.

CALLON, M. \& F. MUNIESA. (2005) 'Economic Markets as Calculative Collective Devices', Organization Studies, vol. 26, no. 8, pp. 1229-1251.

CRUMP, T. (1978) 'Money and Number: The Trojan Horse of Language', Man, vol. 13, no. 4, pp. 503-518.

ENGELBRECHT, S. \& S. HOLMBERG (2012) Svenskars bedömning av offentliga myndigheters verksamhet, SOM-institutet, Göteborg. 
ENGSTRÖM, P. \& B. HOLMLUND (2006) Tax Evasion and Self-Employment in a High-Tax Country: Evidence from Sweden. CESIFO WORKING PAPER1736.

EUROPEAN COMMISSION. TAXATION AND CUSTOMS UNION (2016) Tax Policies in the European Union, 2016 Survey.

FISCALIS TAX GAP PROJECT GROUP (2016) The Concept Of Tax Gaps, Report on VAT Gap Estimations, Brussels.

FORSTATER, M. (2015) Can Stopping 'Tax Dodging' by Multinational Enterprises Close the Gap in Development Finance?, CGD Policy Paper 069. Available at www.cgdev.org (accessed 15 October 2016).

GEMMELL, N., \& J. HASSELDINE. (2012) 'The Tax Gap: A Methodological Review', Working Papers in Public Finance, 09/2012 Victoria University of Wellington School.

GILES, D. E. A. (1997) 'Causality between the Measured and Underground Economies in New Zealand', Applied Economics Letters, vol. 4, no. 1, pp. 63-67.

HASSELDINE, J. \& G. MORRIS. (2013) 'Corporate Social Responsibility and Tax Avoidance: A Comment and Reflection’, Accounting Forum, vol. 37, no. 1, pp. 1-15.

HENRY, J. S. (2012) The Price Of Offshore Revisited. New Estimates For Missing Global Private Wealth, Income, Inequality, and Lost Taxes. Tax Justice Network, Available at http://www.taxjustice.net/cms/upload/pdf/Price of Offshore Revisited 120722.pdf (accessed 10 June 2015).

HMRC (2016a) Measuring Tax Gaps 2016 Edition. Tax Gap Estimates for 2014-15. HM Revenue and Customs.

HMRC (2016b) Measuring Tax Gaps 2016 Edition. Methodological Annex. HM Revenue and Customs.

HOLMES, D. R. (2014. Economy of Words: Communicative Imperatives in Central Banks, University of Chicago Press, Chicago \& London.

HOLMES, D. R. (2009) 'Economy of Words', Cultural Anthropology, vol. 24, no. 3, pp. 381-419.

INTERNAL REVENUE SERVICE. RESEARCH, ANALYSIS \& STATISTICS (2016) Federal Tax Compliance Research: Tax Gap Estimates for Tax Years 2008-2010. 1415 (5-2016). Washington.

KHOSRAVI, S. (2010) 'An Ethnography of Migrant 'Illegality'in Sweden: Included yet Excepted?', Journal of International Political Theory, vol. 6, no. 1, pp. 95-117.

KORNHAUSER, M. E. (2007) 'Tax Morale Approach to Compliance: Recommendations for the IRS', Florida Tax Review, vol. 8, no. 6, pp. 599-634.

LATOUR, B. (1999) Pandora's Hope: Essays on the Reality of Science Studies, Harvard University Press, Cambridge. 
MACKENZIE, D. (2005) 'Opening the Black Boxes of Global Finance', Review of International Political Economy, vol 12, no. 4, pp. 555-576.

MILLER, P. (2008) 'Calculating economic life', Journal of Cultural Economy, vol. 1, no. 1, pp. 5164.

OECD (2008) Monitoring Taxpayers' Compliance: A Practical Guide Based on Revenue Body Experience, Forum On Tax Administration: Compliance Subgroup.

OECD (2010) Overview: Evaluating the Effectiveness of Compliance Risk Treatment Strategies, Forum On Tax Administration: Small/Medium Enterprise (SME) Compliance SubGroup.

OECD (2014) Measures of Tax Compliance Outcomes:A Practical Guide, Centre for Tax Policy and Administration.

PORTER, T. M. (1995) Trust in Numbers: The Pursuit of Objectivity in Science and Public Life, Princeton University Press, Princeton.

RIKSREVISIONEN (2013) Skatteverkets Årsredovisning 2012 samt granskning av uppbördsprocesser, Stockholm, Riksrevisionen.

RILES, A. (2006) ed, Documents : Artifacts of Modern Knowledge, University of Michigan Press, Ann Arbor.

SEABRA LOPES, D. (2015) Number Interception. Journal of Cultural Economy vol. 8, no. 2, pp. 202217.

SKAT Danish Tax and Customs Administration (2016) Kontrolaktiviteter 2016. Styrket regelefterlevelse på skatteområdet.

SKATTEVERKET (2006) Purchasing and Performing Undeclared Work in Sweden: Part 1: Results from Various Studies. Report 4B, Skatteverket, Malmö.

SKATTEVERKET (2007) Svartköp och svartjobb i Sverige. Del 2: Möjliga åtgärder mot svartarbete och bidragsfusk, Skatteverket, Solna.

SKATTEVERKET (2008) Tax Gap Map for Sweden How Was It Created and How Can It Be Used?, Skatteverket, Solna.

SKATTEVERKET (2014) The Development of the Tax Gap in Sweden 2007-12, Skatteverket, Solna.

SLEMROD, J. (2007) 'Cheating Ourselves: The Economics of Tax Evasion', The Journal of Economic Perspectives, vol. 21, no. 1, pp. 25-48.

US DEPARTMENT OF THE TREASURY. INTERNAL REVENUE SERVICE (IRS) (1996) Federal Tax Compliance Research. Individual Income Tax Gap Estimates for 1985, 1988, and 1992, 1415 (4-1996), Washington. 